\title{
Professor Saidi; Founder of the SSK Resident's Forum
}

\author{
James Waweru
}

University of Nairobi

Correspondence to: Dr James Waweru, P.O. Box 36153-00200, Nairobi, Kenya. Email: mayshno@gmail.com

\section{Summary}

The resident's forum is a chapter of the surgical society of Kenya formed by the associate members who are by large surgical residents and medical officers with interest in surgery. It is a platform for continuous surgical education and networking among the associate members. This forum has had a great impact on surgical trainees in the country for now six years, since its inception by Professor Hassan. Professor Hassan held at heart, a great passion for teaching, his love and commitment was like no other. Despite the ever growing number of students both in medical school and residency, professor juggled mentoring his students with commitment amidst work and family life. This, he fulfilled faithfully when there was so much more for him to do. He championed as a premier luminary of

As any great dreamer would envision, professor saw a great opportunity to mentor more residents far and beyond the two universities he formally lectured, after he was elected into the council of the surgical society of Kenya. He recognised the need for raising the visibility of trainee surgeons in the professional society and saw an opportunity of continued mentorship in academics and social life among the residents themselves and from senior colleagues in the society. His initial plan was to have residents engage in more frequent academic discussions and cross-mentorship beyond the single annual conference of the surgical society of Kenya. Many challenges set themselves ahead including resources to finance the residents meetings and mentors to facilitate the events. Professor shared his thoughts with his mentees who became very interested in participating in the forum. With the help of his colleagues from the University of Nairobi and the College of Surgeons of East Central and Southern clinical practice to hundreds of medical students and residents. His teachings represented the truth in medical practice, correcting errors and advancing towards standard practice. He became a mentor to many students in University of Nairobi medical school and residents in Nairobi and Aga Khan University.

Key words: Resident forum, Surgical society, Hassan Saidi

Ann Afr Surg. 2018;15(2):68-69

DOI:http://dx.doi.org/10.4314/aas.v15i2.7

(C) 2018 Author. This work is licensed under the

Creative Commons Attribution 4.0 International

License.

Conflicts of Interest: None

Funding: None

Africa (COSECSA) the first resident's forum was held on $23^{\text {rd }}$ November 2013 at Arziki conference centre in Chiromo campus, University of Nairobi. The theme was 'hot topics in surgery' that had vibrant participation by attending residents. With the success in the initial meeting professor had the dream to make the forum accessible to all. There was still a challenge of availability of faculty members on the weekend and busy residents on weekdays. With the determination to breach the hurdles, professor arranged with the department of surgery and the residents of the Aga Khan University teaching hospital for the second forum on $11^{\text {th }}$ December 2014. The forum was again very successful and the momentum had now begun. The third resident's forum was held on $13^{\text {th }}$ June 2015 at Kijabe Hospital. Professor Saidi was out of the country however the residents who were growing with enthusiasm arranged with attendance of three faculty members from Aga Khan and Kijabe hospital. 
The following year professor was very instrumental in organising the residents' forum. He challenged the residents to look for sponsors themselves and run the programme. This saw the beginning of invitation of corporate sponsors into resident's forum. The fourth resident's forum was held in lecture theatre III in University of Nairobi on $11^{\text {th }}$ June 2016 . The theme was "evidence based surgical practice through research and innovation". Professor was in attendance from the beginning to the very end and made his remarks on the future of the resident's forum. He was impressed at the organisation done fully by residents and the increased number of resident attendees. The following year, Moi teaching and referral hospital residents hosted the resident's forum at Noble hotel in Eldoret on $17^{\text {th }}$ June 2017. Again fully organised by residents and sponsored by corporate partners. The theme was "new frontiers in surgical oncology in Kenya". Professor requested to see the days programme and gave his apologies for the forum in Eldoret. At the moment the residents of Mater hospital in Nairobi are organising to host this 2018 resident's forum. In this meeting another teaching hospital will be voted to host the following year and the trend will continue in legacy of Professor Saidi. 